\title{
EFEKTIVITAS MODEL PEMBELAJARAN ROLE PLAYING DITINJAU DARI HASIL BELAJAR MATEMATIKA SISWA SMP NEGERI 21 KOTA BENGKULU
}

\author{
Tiara Fitry ${ }^{1}$, Syafdi Maizora ${ }^{2}$, dan Rusdi ${ }^{3}$ \\ Program Studi Pendidikan Matematika, FKIP Universitas Bengkulu \\ Email: 17itrytiara8@ gmail.com, ${ }^{2}$ syafdiichiemaizora@ unib.ac.id, ${ }^{3}$ rusdipendmat12@ gmail.com
}

\begin{abstract}
Abstrak
Tujuan penelitian ini untuk mengetahui apakah hasil belajar matematika siswa menggunakan model role playing lebih dari hasil belajar matematika siswa menggunakan pembelajaran ekspositori di SMPN 21 Kota Bengkulu pada pokok bahasan aritmetika sosial. Jenis penelitian ini adalah Quasi Experiment (Eksperimen semu) dengan desain penelitian yaitu The Nonequivalent Posttest-only Control Group Design. Instrumen dalam penelitian ini adalah tes hasil belajar berupa tes akhir (posttest) yang berbentuk tes essay. Analisis uji hipotesis menggunakan uji-t untuk sampel independen, diperoleh bahwa $t_{\text {hitung }}=1,120$ dan $t_{\text {tabel }}=2,006$, maka $t_{\text {hitung }} \leq$ $t_{\text {tabel }}$ yang berarti $H_{0}$ diterima. Hal ini didukung oleh perhitungan melalui SPSS versi 23 yang menunjukkan bahwa nilai Sig. (2-tailed) $=0,159$ dengan taraf signifikan $(\alpha)=0,05$, sehingga Sig. (2-tailed) $>(\alpha)$. Hasil penelitian ini adalah hasil belajar matematika siswa menggunakan model role playing sama dengan hasil belajar siswa menggunakan pembelajaran ekspositori di SMP Negeri 21 Kota Bengkulu
\end{abstract}

Kata Kunci: hasil belajar matematika, model role playing, pembelajaran ekspositori.

\begin{abstract}
This research was purposed to know difference the student learning result of mathematics by using role playing learning model with expository learning on the subject of aritmetika sosial at the grade VII of Junior High School 21 Kota Bengkulu. This research was a quasi-experimental research design with nonequivalent posttestonly control group design. The instrument used in this research is posttest. The analysis hypotesis test used ttest for independent samples, hence obtained that $t_{\text {value }}=1,120$ and $t_{\text {list }}=2,006$, thus, $t_{\text {value }} \leq t_{\text {list }}$ which means $H_{0}$ is granted. SPSS version 23 program showed that the value of Sig. (2-tailed) $=0,159$ with significance level $(\alpha)=0,05$, thus Sig. (2-tailed) $>(\alpha)$. The result of mathematics by using role playing model with the expository learning at SMPN 21 Bengkulu is equivalent.
\end{abstract}

Keyword: results outcomes, role playing model, expository learning

\section{PENDAHULUAN}

Matematika merupakan alat untuk mengembangkan cara berpikir (Hudojo, 2005: 37). Tujuan khusus pengajaran matematika menurut Soedjadi (2000: 44) di Sekolah Lanjutan Pertama yaitu peserta didik mempunyai pandangan yang cukup luas dan memiliki sikap logis, kritis, cermat, kreatif dan disiplin serta menghargai kegunaan matematika. Penerapan kurikulum 2013 tersebut sangat mengharapkan siswa menjadi aktif, kreatif, dan inovatif sesuai dengan tujuan pembelajaran matematika. Namun, pada kenyataannya, harapan tersebut belum tercapai pada beberapa materi yang ada pada mata pelajaran matematika, salah satunya yaitu aritmetika sosial.

Berdasarkan hasil pengamatan dan wawancara dengan ibu Desi Efmasari, S.Pd. selaku guru mata pelajaran matematika kelas VII di SMP Negeri 21
Kota Bengkulu pada hari Kamis Tanggal 18 Januari 2018, diketahui bahwa kurikulum yang digunakan adalah kurikulum 2013. Masalah yang ditemukan pada saat proses pembelajaran yaitu kurangnya ketertarikan peserta didik terhadap mata pelajaran matematika yang selama ini hanya mencatat rumus hingga membuat peserta didik bosan, kurangnya partisipasi peserta didik terhadap materi yang diajarkan sehingga menyebabkan siswa pasif.

Salah satu upaya yang dilakukan untuk menghadapi permasalahan di atas yaitu dengan menerapkan model yang dapat menimbulkan minat siswa untuk aktif. Suprijono (2014: 46) menyatakan model pembelajaran ialah pola yang digunakan sebagai pedoman dalam merencanakan pembelajaran dikelas. Model pembelajaran yang tepat diterapkan di dalam kelas diharapkan dapat membuat siswa dapat berperan aktif pada saat proses 
pembelajaran berlangsung, selain itu kegiatan belajar menggunakan model pembelajaran yang tidak didasarkan pada keaktifan siswa akan menyebabkan proses belajarnya hanya terjadi dengan hafalan saja tanpa pemahaman yang menyebabkan siswa sering lupa atau bahkan tidak mengingatnya lagi materi itu selesai diajarkan.

Model yang menggunakan aspek keaktifan dan hasil belajar siswa salah satunya yaitu model pembelajaran role playing. Lestari dan Yudhanegara (2015: 72) role playing adalah model pembelajaran yang dalam proses pelaksanaannya melibatkan kolaborasi dengan siswa. Sejalan dengan hal tersebut, Fogg (Huda, 2013: 208) menyatakan role playing atau bermain peran adalah sejenis permainan gerak yang di dalamnya ada tujuan, aturan, dan edutainment.

Fogg (Huda, 2013: 208) menyatakan role playing atau bermain peran adalah sejenis permainan gerak yang didalamnya ada tujuan, aturan, dan edutainment. Dapat dikatakan bahwa role playing merupakan salah satu model pembelajaran yang dapat diterapkan pada kurikulum 2013, dikarenakan pada model ini banyak aktivitas yang melibatkan siswa, dari mulai siswa yang mengutarakan konsep suatu materi, siswa mengamati, siswa berpikir, hingga siswa menarik kesimpulan suatu materi yang mereka dapat melalui adegan bermain peran.

Langkah-langkah role playing menurut Hamzah dan Muhlisrarini (2014: 168), yaitu:

1. Guru menyusun/menyiapkan skenario yang akan ditampilkan

2. Menunjuk beberapa siswa untuk mempelajari skenario dalam waktu beberapa hari sebelum $\mathrm{KBM}$

3. Guru membentuk kelompok siswa yang anggotanya 5 orang

4. Memberikan penjelasan tentang kompetensi yang ingin dicapai,

5. Memanggil para siswa yang sudah ditunjuk untuk melakonkan skenario yang sudah dipersiapkan

6. Masing-masing siswa berada dikelompoknya sambil mengamati skenario yang sedang diperagakan

7. Setelah selesai ditampilkan masing-masing siswa diberikan lembar kerja untuk membahas penampilan masing-masing kelompok

8. Masing-masing kelompok menyampaikan hasil kesimpulannya

9. Guru memberikan kesimpulan secara umum
10. Evaluasi

11. Penutup

Primasari, dkk (2013:2) menyatakan bahwa langkah-langkah penggunaan role playing ada sembilan, yaitu:

1. Pemanasan/membangkitkan semangat kelompok

2. Pemilihan partisipan/peserta

3. Memilih dan mengatur arena panggung

4. Menyiapkan pengamat

5. Memainkan peran

6. Diskusi dan evaluasi

7. Memerankan kembali

8. Berdiskusi dan evaluasi kedua

9. Saling berbagi pengalaman dan melakukan generalisasi

Berdasarkan kajian tersebut pembelajaran memainkan peran maka pembelajaran matematika akan lebih diminati siswa. Hal ini menunjang pencapaian hasil pembelajaran. Sehingga dilaksanakan penelitian dengan tujuan mengetahui efektifitas model pembelajaran role playing ditilihat dari ketercapaian hasil belajar matematika siswa. Selain itu, penelitian ini juga memberikan alternative inovasi dalam belajar matematika bagu guru matematika SMP Kota Bengkulu.

\section{METODE PENELITIAN}

Jenis penelitian yang dilaksanakan adalah penelitian eksperimen. Penelitian eksperimen adalah suatu cara untuk mencari hubungan sebab akibat (hubungan kausal) antara dua faktor yang sengaja ditimbulkan oleh peneliti dengan mengeliminasi atau mengurangi atau menyisihkan faktor-faktor lain yang mengganggu (Arikunto, 2014: 9).

Penelitian ini dilaksanakan di SMP Negeri 21 Kota Bengkulu. Penelitian ini dilaksanakan pada semester genap kelas VII Tahun Pelajaran 2017/2018. Pengambilan sampel pada penelitian ini menggunakan teknik purposive sampling. Purposive sampling yaitu teknik penentuan sampel dengan pertimbangan tertentu sesuai dengan kebutuhan dari penelitian yang akan dilakukan (Lestari dan Yudhanegara, 2017: 101).

Pada penelitian ini, sampel ditentukan berdasarkan nilai rata-rata ulangan matematika kelas VII yang sama dan jumlah siswa yang sama yaitu kelas VII 1 (kelas eksperimen) dan VII 7 (kelas kontrol). Selain kelas sampel eksperimen dan kelas kontrol tersebut, terdapat kelas uji coba yang digunakan untuk menguji soal posttest dari rata-rata nilai tersebut di ambil satu kelas yang memiliki 
varians yang tidak jauh berbeda (homogen). Kelas yang menjadi kelas uji coba yaitu kelas VII 4.

Instrumen yang digunakan pada penelitian ini berupa lembar tes. Lembar tes tersebut berupa soalsoal uraian yang digunakan sebagai soal posttest untuk mengetahui hasil belajar peserta didik. Pada penelitian ini, soal yang digunakan sebagai instrumen penelitian terlebih dahulu divalidasi dengan uji ahli yaitu dosen dan guru mata pelajaran matematika kelas VII SMP Negeri 21 Kota Bengkulu. Kemudian untuk instrumen soal posttest diujicobakan pada kelas uji coba. Hasil uji coba tersebut dianalisis berdasarkan validitas empiris, reliabilitas, taraf kesukaran dan daya beda soal kemudian dipilih soal yang dianggap baik untuk soal posttest.

\section{HASIL DAN PEMBAHASAN HASIL PENELITIAN}

Uji validitas butir soal dilakukan dengan menggunakan rumus korelasi prodduct moment:

$$
r_{x y}=\frac{N \sum X Y-\left(\sum X\right) \cdot\left(\sum Y\right)}{\sqrt{\left[N \sum X^{2}-\left(\sum X\right)^{2}\right] \cdot\left[N \sum Y^{2}-\left(\sum Y\right)^{2}\right]}}
$$

dengan taraf signifikansi 5\% menunjukkan bahwa dari 5 soal diperoleh semua soal valid karena $r_{x y}>$ $r_{\text {tabel }}$. Oleh karena itu, semua soal layak digunakan pada penelitian ini.

Uji reliabilitas soal dilakukan dengan menggunakan rumus Alpha. Dari perhitungan yang telah peneliti lakukan dengan bantuan Software Microsoft Excel 2007 diperoleh bahwa nilai koefisien reliabilitas tes secara keseluruhan adalah 0,619 . Hal ini menunjukkan bahwa soal posttest berada pada koefisien korelasi $0,40 \leq r_{11}<0,70$ yang artinya soal posttest reliable atau dapat dipercaya dengan korelasi yang sedang dan interpretasi reliabilitasnya cukup baik. Berdasarkan hasil perhitungan tersebut soal posttest sudah layak untuk digunakan.

Hasil uji taraf kesukaran soal menggunakan rumus $I K=\frac{\bar{X}}{S M I}$ menunjukkan bahwa dari 5 butir soal yang diujicobakan terdapat 3 soal dengan kriteria taraf kesukaran sedang yakni soal nomor 1,2 dan 5, dua soal mudah yakni soal nomor 3 dan 4 .

Uji daya pembeda menggunakan rumus $D P=\frac{\bar{X}_{A}-\bar{X}_{B}}{S M I}$ menghasilkan indeks pembeda 3 butir soal posttest berada pada $0,00<D P \leq 0,20$ dengan interpretasi daya pembeda buruk, sedangkan indeks pembeda 2 butir soal berada pada $0,20 \leq D P<$ 0,40 dengan interpretasi daya pembeda cukup.
Berdasarkan hasil rekapitulasi validitas empiris, maka butir soal yang digunakan adalah soal nomor 2 dan 5. Untuk soal nomor 1,3 dan 4 harus direvisi terlebih dahulu sebelum digunakan untuk posttest kelas sampel.

Pembelajaran pada kelas eksperimen menggunakan model pembelajaran role playing, sedangkan pada kelas kontrol menggunakan pembelajaran ekspositori. Proses pembelajaran pada penelitian ini dilaksanakan dalam 5 kali pertemuan untuk setiap kelas baik kelas eksperimen (VII 1) maupun kelas kontrol (VII 7). Materi yang diajarkan dalam penelitian ini adalah aritmetika sosial. Pembelajaran dilaksanakan dalam 12 pertemuan, yaitu 6 pertemuan untuk kelas yang menggunakan model pempelajaran role playing dan 6 pertemuan untuk kelas kontrol yang menggunakan pembelajaran ekspositori. Pembelajaran matematika di SMP Negeri 21 Kota Bengkulu dilaksanakan sebanyak 2 kali dalam seminggu dengan alokasi waktu $2 \times 40$ menit untuk setiap 1 jam pelajaran.

Kelas eksperimen pembelajaran sudah mulai melibatkan aktivitas siswa. Pola pembelajaran pada kelas eksperimen dimulai dari siswa bermain peran sesuai arahan guru, setelah itu siswa diminta untuk menemukan kesimpulan materi dengan cara menyelesaikan setiap langkah pada LKPD yang diberikan guru kepada tiap kelompok. Kemudian, masing-masing kelompok menyampaikan hasil kesimpulannya. Pada LKPD juga terdapat beberapa soal latihan yang harus dikerjakan oleh tiap kelompok, sedangkan pada kelas kontrol pembelajaran masih banyak terpusat kepada guru, dimana guru menjelaskan materi secara langsung dan siswa hanya mendengarkan dan mencatat.

Kegiatan pembelajaran di kelas kontrol menggunakan pembelajaran ekspositori dengan tahapan yang terdapat pada pembelajaran ekspositori, yaitu diawali dengan persiapan, dimana guru dan siswa mempersiapkan buku serta alat tulis. Kemudian tahap penyajian. Pada tahap ini guru menjelaskan submateri. Tahap berikutnya adalah korelasi. Tahap ini merupakan tahap dimana guru memberikan contoh yang berkaitan dengan submateri yang diajarkan. Selanjutnya tahap menyimpulkan, guru bersama siswa menyimpulkan materi yang telah dijelaskan. Tahap terakhir pembelajaran ini adalah mengaplikasikan. Pada tahap inilah siswa mengerjakan beberapa soal latihan yang diberikan guru terkait dengan materi 
yang diajarkan untuk melihat seberapa jauh siswa mengerti tentang materi tersebut.

Setelah melaksanakan pembelajaran dengan model roel playing pada materi aritmetika sosial, kemudian siswa diberikan posttest. Posttest yang dilakukan dikelas eksperimen diikuti oleh 27 siswa. Berdasarkan data posttest siswa, diperoleh hasil sebagai berikut:

Tabel 1 Deskriptif Hasil Tes Kelas Role Playing

\begin{tabular}{|l|c|}
\hline \multicolumn{1}{|c|}{ Deskripsi } & Nilai \\
\hline Nilai Rata-rata & 73,07 \\
\hline Nilai Tertinggi & 97 \\
\hline Nilai Terendah & 42 \\
\hline Varians & 218,687 \\
\hline Simpangan Baku & 14,788 \\
\hline Skewnes & $-0,479$ \\
\hline
\end{tabular}

Tabel 1 menunjukkan nilai rata-rata hasil tes belajar siswa yang menggunakan model pembelajaran role playing adalah sebesar 73,07 dan simpangan baku sebesar 14,788. Nilai skewness adalah $-0,479$ yang berada pada rentang $-1,96<\mathrm{x}<$ 1,96 secara deskriptif menunjukkan bahwa data hasil tes belajar siswa pada kelas eksperimen berdistribusi normal

Kelas VII 7 menerapkan pembelajaran ekspositori. Setelah melaksanakan pembelajaran dengan pembelajaran ekspositori pada materi aritmetika sosial, kemudian siswa diberikan posttest. Posttest yang dilakukan dikelas kontrol diikuti oleh 27 siswa, diperoleh hasil sebagai berikut:

Tabel 2 Analisis Deskriptif Hasil Tes Kelas Ekspositori

\begin{tabular}{|l|c|}
\hline \multicolumn{1}{|c|}{ Deskripsi } & Nilai \\
\hline Nilai Rata-rata & 66,63 \\
\hline Nilai Tertinggi & 96 \\
\hline Nilai Terendah & 35 \\
\hline Varians & 329,165 \\
\hline Simpangan Baku & 18,143 \\
\hline Skewnes & $-0,348$ \\
\hline
\end{tabular}

Tabel 2 menunjukkan bahwa nilai rata-rata hasil tes belajar siswa yang menggunakan pembelajaran ekspositori adalah sebesar 66,63 dan simpangan baku sebesar 18,143. Nilai skewness adalah $-0,348$ yang berada pada rentang $-1,96<\mathrm{x}<1,96$ secara deskriptif menunjukkan bahwa data hasil tes belajar siswa pada kelas kontrol berdistribusi normal.
Dari rata-rata nilai kedua kelas sampel dapat diketahui bahwa kelas eksperimen memiliki rata-rata yang tinggi daripada kelas kontrol. Analisis skor rata-rata yang diperoleh siswa disajikan seperti pada tabel berikut.

Tabel 3 Rekap Skor Rata-Rata Per Butir soal

\begin{tabular}{|c|c|c|}
\hline No & $\begin{array}{c}\text { Kelas } \\
\text { Eksperimen }\end{array}$ & $\begin{array}{c}\text { Kelas } \\
\text { Kontrol }\end{array}$ \\
\hline 1. & 16,11 & 15,29 \\
\hline 2. & 13,18 & 12,14 \\
\hline 3. & 12,55 & 11,74 \\
\hline 4. & 12,44 & 11,51 \\
\hline 5. & 18,77 & 15,62 \\
\hline Total & 73,07 & 66,63 \\
\hline
\end{tabular}

Hasil penelitian di kelas VII SMP Negeri 21 Kota Bengkulu pada materi aritmetika sosial menunjukkan bahwa nilai rata-rata hasil belajar matematika siswa yang menggunakan model pembelajaran role playing secara deskriptif lebih dari nilai rata-rata hasil belajar matematika siswa yang menggunakan pembelajaran ekspositori. Namun, berdasarkan hasil perhitungan uji-t menunjukkan bahwa tidak terdapat perbedaan hasil belajar matematika siswa antara model pembelajaran role playing dan pembelajaran ekspositori. Tabel di bawah ini adalah hasil perhitungan uji hipotesis kelas sampel:

Tabel 4 Hasil Uji-t Posttest Kelas Sampel

\begin{tabular}{|c|c|c|}
\hline $\boldsymbol{t}_{\text {hitung }}$ & $\boldsymbol{t}_{\text {tabel }}$ & Keterangan \\
\hline 1,120 & 2,006 & $H_{0}$ diterima \\
\hline
\end{tabular}

Hasil perhitungan menggunakan Ms. Excel 2007 didapat nilai $t_{\text {hitung }}=1,120$ dan $t_{\text {tabel }}=2,006$, maka $t_{\text {hitung }} \leq t_{\text {tabel }}$. Jadi, $H_{0}$ diterima. Perhitungan menggunakan SPSS versi 23 menghasilkan nilai Sig. (2-tailed) $=0,159$ dengan taraf signifikan $(\alpha)=0,05$. Sehingga, Sig. (2-tailed) $>(\alpha)$, maka $H_{0}$ diterima, seperti yang tertera pada tabel berikut:

Tabel 5 Uji-t Posttest Kelas Sampel dengan SPSS

\begin{tabular}{|c|c|c|}
\hline $\begin{array}{c}\text { Sig. } \\
(\mathbf{2 -} \\
\text { tailed) }\end{array}$ & $\begin{array}{c}\text { Taraf } \\
\text { signifikan }(\boldsymbol{\alpha})\end{array}$ & Keterangan \\
\hline 0,159 & 0,05 & $\begin{array}{c}H_{0} \text { diterima } \\
\text { sehingga } H_{1} \text { ditolak }\end{array}$ \\
\hline
\end{tabular}


Jadi, disimpulkan bahwa tidak terdapat perbedaan hasil belajar matematika siswa antara model pembelajaran role playing dan pembelajaran ekspositori di kelas VII di SMP Negeri 21 Kota Bengkulu.

\section{PEMBAHASAN}

Dilihat dari rata-rata siswa per butir soal, ratarata siswa kelas eksperimen lebih dari rata-rata siswa kelas kontrol. Hasil posttest yang dikerjakan siswa memperlihatkan banyaknya siswa menjawab benar soal posttest, yakni:

Tabel 6 Banyak Siswa yang Menjawab Benar untuk

\begin{tabular}{|c|c|c|}
\multicolumn{3}{|c|}{ Tiap Soal } \\
\hline No & $\begin{array}{c}\text { Kelas } \\
\text { Eksperimen }\end{array}$ & $\begin{array}{c}\text { Kelas } \\
\text { Kontrol }\end{array}$ \\
\hline 1. & 1 & 0 \\
\hline 2. & 5 & 0 \\
\hline 3. & 2 & 1 \\
\hline 4. & 5 & 4 \\
\hline 5. & 5 & 2 \\
\hline
\end{tabular}

Berdasarkan tabel 6, terlihat bahwa pada kelas eksperimen ada 1 siswa yang menjawab dengan sempurna soal posttest nomor 1 dan ada 5 siswa yang menjawab soal posttest nomor 2 dengan sempurna. Sedangkan pada kelas kontrol tidak ada siswa yang menjawab dengan sempurna soal posttest nomor 1 dan nomor 2 . Hal ini dikarenakan siswa tidak menuliskan rumus dan salah dalam perhitungan.

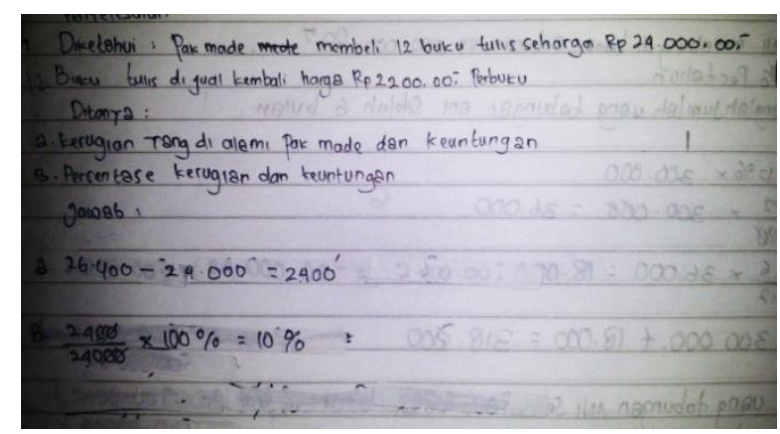

Gambar 1 Salah Satu Jawaban Nomor 1 Posttest Siswa Kelas Kontrol

Gambar 1 memperlihatkan bahwa siswa langsung menuliskan hasil tanpa menuliskan rumusnya. Padahal rumus yang ditulis siswa sangat berpengaruh terhadap skor. Pada gambar di atas, siswa langsung menjawab $26.400-24.000=2.400$ dan $\frac{2.400}{24.000} \times 100 \%=10 \%$. Jawaban yang benar, seharusnya:

keuntungan $=$ harga jual - harga beli

$=$ Rp. $26 \cdot 400,00-$ Rp. $24 \cdot 000,00$

$$
=\text { Rp. } 2 \cdot 400,00
$$

Jadi, keuntungan Pak Made adalah Rp. 2.400,00. dan

$$
\begin{aligned}
\text { persentase keuntungan } & =\frac{\text { untung }}{\text { harga beli }} \times 100 \% \\
= & \frac{\text { Rp. } 2400,00}{\mathrm{Rp} .24 .000,00} \times 100 \% \\
= & 10 \%
\end{aligned}
$$

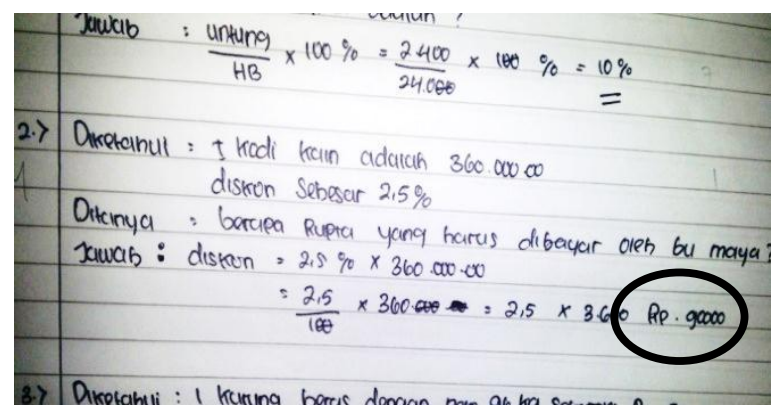

Gambar 2 Salah Satu Jawaban Nomor 2 Posttest Siswa Kelas Kontrol

Pada soal nomor 2 juga terlihat bahwa siswa tidak menuliskan rumus diskon terlebih dahulu dan juga dalam proses perhitungan jawaban yang seharusnya adalah Rp. 9.000 tetapi siswa menuliskan Rp. 90.000. Padahal, nilai Rp. 9.000 dan Rp. 90.000 sangat jauh berbeda.

Soal nomor 3 dan 4, jumlah siswa yang menjawab dengan benar dari kedua kelas sampel tidak jauh berbeda, dimana pada kelas eksperimen yang menggunakan model role playing yang dapat menjawab soal nomor 3 dengan benar ada 2 siswa dan soal nomor 4 yang dapat menjawab dengan benar ada 5 siswa. Sedangkan kelas kontrol yang menggunakan pembelajaran ekspositori yang dapat menjawab soal nomor 3 ada 1 siswa dan soal nomor 5 ada 4 siswa menjawab benar.

Kelas eksperimen ada 5 siswa yang menjawab benar pada soal nomor 5, sedangkan pada kelas kontrol ada 2 siswa yang menjawab benar. Faktor yang menyebabkan siswa tidak sempurna menjawab karena siswa tidak menuliskan rumusnya dan tidak teliti dalam menghitung, juga disebabkan kesalahan menulis angka. 


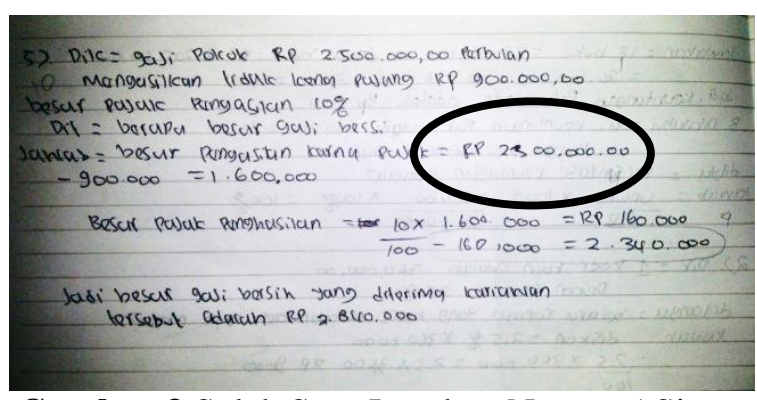

Gambar 3 Salah Satu Jawaban Nomor 5 Siswa Kelas Kontrol

Kesalahan siswa saat menuliskan jawaban dapat dilihat pada gambar 3. Pada gambar tersebut, kesalahan pada jawaban siswa, yaitu siswa tidak menuliskan rumus dan siswa salah menulis angka. Angka yang seharusnya Rp. 2.500.000, ditulis Rp. 2.300.000.

Berdasarkan tabel 3 dan 4, terlihat bahwa ratarata nilai posttest kelas eksperimen yang menggunakan model role playing lebih dari rata-rata nilai posttest kelas kontrol yang menggunakan pembelajaran ekspositori. Pada kelas eksperimen terlihat lebih banyak siswa yang menjawab soal dengan sempurna dibandingkan kelas kontrol. Hal ini dikarenakan selama proses pembelajaran di kelas, siswa pada kelas eksperimen dituntut aktif dan berpikir mandiri sebelum menemukan kesimpulan. Siswa juga terlatih dalam mencari informasi, menghubungkan informasi yang ada untuk menemukan informasi yang baru, ditambah dengan diskusi kelompok yang dapat membuat siswa saling membantu setiap ada kesulitan dan ketidakpahaman yang dialami, serta siswa terlatih mengerjakan soal secara sistematis dengan bantuan LKPD.

Sedangkan pada kelas kontrol, selama proses pembelajaran di kelas siswa pasif karena hanya mendengarkan dan mencatat apa yang disampaikan oleh guru tanpa banyak berpikir darimana rumus dan hasil itu diperoleh. Ditambah lagi tidak ada keinginan siswa untuk mengetahui bagaimana proses mendapatkan rumus dan hasil tersebut dan kurangnya keseriusan siswa dalam mengikuti proses pembelajaran.

Hasil penelitian menunjukkan adanya pengaruh penggunaan model role playing terhadap hasil pembelajaran matematika siswa. Hasil penelitian ini didukung oleh penelitia terhadulu yaitu penelitian yang dilakukan oleh Pratama \& Fatahillah (2017) menunjukkan adanya peningkatan hasil belajar dan aktivitas siswa setelah diberikan pembelajaran role playing.

\section{PENUTUP}

\section{Kesimpulan}

Berdasarkan penelitian yang telah dilakukan pada siswa kelas VII 1 dan kelas VII 7 di SMP Negeri 21 Kota Bengkulu pada materi aritmetika sosial dapat disimpulkan bahwa hasil belajar matematika siswa menggunakan model pembelajaran role playing sama dengan hasil belajar matematika siswa menggunakan pembelajaran ekspositori di SMP Negeri 21 Kota Bengkulu.

Kesimpulan tersebut didapat dari hasil perhitungan pengujian hipotesis menggunakan uji-t melalui Ms.Excel 2007. $t_{\text {hitung }}=1,120$ dan $t_{\text {tabel }}=2,006$, maka $t_{\text {hitung }} \leq t_{\text {tabel }}$ yang berarti $H_{0}$ diterima. Hal ini didukung oleh perhitungan melalui SPSS yang menunjukkan bahwa nilai Sig. (2-tailed) $=0,159$ dengan taraf signifikan $(\alpha)=0,05$, sehingga Sig. $(2$-tailed $)>(\alpha)$.

\section{Saran}

Saran yang dapat peneliti berikan berdasarkan hasil penelitian yang telah dilakukan adalah 1) Agar semua siswa dapat aktif dalam proses pembelajaran role playing, guru harus kreatif membuat skenario dan membangun semangat siswa dalam bermain peran, 2) Kegiatan role playing dapat dilakukan di luar kelas sebagai variasi pembelajaran agar siswa tidak bosan, 3) Pada pembelajaran ekspositori, sebaiknya guru membuat suatu peraturan yang tegas kepada siswa yang tidak mengerjakan tugas.

\section{DAFTAR PUSTAKA}

Arikunto, Suharsimi. (2014). Prosedur Penelitian Suatu Pendekatan Praktik. Jakarta : Rineka Cipta.

Dimyati dan Mudjiono. (2015). Belajar dan Pembelajaran. Jakarta: Rineka Cipta

Hamzah, A dan Muhlisrarini. (2014). Perencanaan dan Strategi

Pembelajaran Matematika. Jakarta: PT

Raja Grafindo Persada.

Huda, Miftahul. (2014). Model-model Pengajaran dan Pembelajaran. Yogyakarta: Pustaka Pelajar.

Hudojo. (2005). Pengembangan Kurikulum dan Pembelajaran Matematika. Malang: Universitas Negeri Malang.

Lestari dan Yudhanegara, dkk. (2017). Penelitian Pendidikan Matematika. Bandung: Refika Aditama. 
Pratama, R., dan Fatahillah. (2017). Implementasi Metode Pembelajaran Role Playing Pada Aritmetika Sosial Untuk Meningkatkan Hasil Belajar dan Aktivitas Siswa. Jurnal Edukasi, 2017, IV(2) : 27-30 $\begin{array}{ccc}\text { Primasari, dan } & \text { Rustiana. } & \text { (2013). } \\ \text { "Penggunaan Model Role Playing }\end{array}$ untuk Peningkatan Pembelajaran Matematika Bagi Siswa Kelas IV SDN 1 Lundong". Artikel Publikasi.
Soedjadi, R. (2000). Kiat Pendidikan Matematika di Indonesia. Jakarta: Direktorat Jenderal Pendidikan Tinggi.

Suprijono, Agus. (2014). Cooperative Learning. Yogyakarta: Pustaka Pelajar.

Slameto. (2013). Belajar dan Faktor-Faktor yang Mempengaruhi. Jakarta: Rineka Cipta.. 